\title{
Two caves in western Honduras are important for bat conservation: first checklist of bats in Santa Bárbara
}

\author{
Manfredo Alejandro Turcios-Casco,2, Diego Iván Ordoñez Mazier ${ }^{3}$, \\ José Alejandro Soler Orellana ${ }^{3,4}$, Hefer Daniel Ávila-Palma ${ }^{3}$, \\ Eduardo Javier Ordoñez Trejo ${ }^{3}$
}

\begin{abstract}
I Departamento de Vida Silvestre, Instituto Nacional de Conservación y Desarrollo Forestal, Áreas Protegidas y Vida Silvestre, Francisco Morazán, Honduras 2 Biological Institute, Tomsk State University, Tomsk, Russia 3 Escuela de Biología, Facultad de Ciencias, Universidad Nacional Autónoma de Honduras, Francisco Morazán, Honduras 4 Colección Privada y Centro de Rescate de Fauna Silvestre "El Ocotal", Francisco Morazán, Honduras
\end{abstract}

Corresponding author: Manfredo Alejandro Turcios-Casco (manturcios21@gmail.com)

Academic editor: Oana Moldovan | Received 14 April 2019 | Accepted 11 June 2019 | Published 27 June 2019

http://zoobank.org/06DA9435-90EA-43DD-A294-BBB502142FAB

Citation: Turcios-Casco MA, Mazier DIO, Orellana JAS, Ávila-Palma HD, Trejo EJO (2019) Two caves in western Honduras are important for bat conservation: first checklist of bats in Santa Bárbara. Subterranean Biology 30: 41-55. https://doi.org/10.3897/subtbiol.30.35420

\begin{abstract}
Caves are important reservoirs for species, including bats, but in Honduras there is little known information about these biodiverse ecosystems. We describe the importance of two caves in Ceguaca in western Honduras, based on the species richness of each cave. From December 2015 to May 2016, we used three mist-nets in seven journeys (74.27 mist-net/hours). We captured 139 bats belonging to 23 species of four families. We recorded 10 species in the crop of Quita Sueño, 10 in the cave of El Peñón, and 12 in the cave of Monte Grueso. In overall, 17\% of the bats were captured in the crops of Quita Sueño, 62\% in the cave of Monte Grueso, and $21 \%$ in the cave of El Peńón. About $9 \%$ of bat species of the total account for Honduras could be found in the cave of El Peñón, and 10\% in the cave of Monte Grueso. If we consider the number of the species that have been recorded since 1979, between 20.9 and $49.2 \%$ of the expected species are still unrecorded, this suggests that despite low sampling effort there is a high diversity. However, the diversity of bats species using these caves embraced on the Tropical Dry Forest of Ceguaca is threatened by the fragmentation of the ecosystem due to the following reasons: intentional fires in the caves, extensive cattle raising, replacement of native plants with extensions of crops, and human-vampire conflicts (Desmodus rotundus).
\end{abstract}

Copyright M.A.Turcios-Casco et al. This is an open access article distributed under the terms of the Creative Commons Attribution License (CC BY 4.0), which permits unrestricted use, distribution, and reproduction in any medium, provided the original author and source are credited. 


\section{Keywords}

Ceguaca, Chiroptera, Mammalia, subterranean ecosystems, Tropical Dry Forest

\section{Introduction}

Caves are reservoirs for exceptional levels of endemic and threatened species, very high levels of genetic uniqueness, and they harbor unconventional taxa such as blind fishes, crustaceans, worms, and many other groups, including bats (Medellín et al. 2017). These ecosystems enclosed unique features for housing bats such as the complete or partial absence of light, constant temperature, and high air humidity (Deleva and Chaverri 2018).

Caves are also considered as a complex system with a variety of microclimates and roosting conditions for bats (Rodríguez-Durán 2009; Furey and Racey 2016). In other cases, bats are so abundant that they can significantly modify the caves by altering their microclimate conditions and providing important amounts of guano, which is an essential food source for trophic chainsin most caves (Deleva and Chaverri 2018). In return, caves provide to bats a refuge from predators, inconstant weather, and a critical venue for social interactions, reproduction, hibernation, roosting and even alimentation (Furey and Racey 2016).

On the tropical regions of America, bat caves have been studied in Puerto Rico (Rodríguez-Durán 1998), West Indies (Rodríguez-Durán 2009), Mexico (Medellín et al. 2017), Brazil (Bichuette et al. 2018), and Costa Rica (Deleva and Chaverri 2018). Recently, in Honduras, there are records by Divoll and Buck (2013) of some bat species captured in caves: Phyllostomus hastatus and Balantiopteryx io captured in Río Masca, Piedra Cocha in Cortés (northern Honduras); and Sturnira hondurensis (referred as S. ludov$i c i$ ) in San Juancito, Parque Nacional La Tigra in Francisco Morazán (central Honduras). After those records, nothing is known about cave-dwelling bats in Honduras recently.

Chiroptera is the order with more mammalian species in Honduras, which is represented by approximately 114 species (Mora et al. 2018). Even though there is a high diversity of bats in Honduras, information of roosting sites, ecology, natural history, and systematic studies of each species is scarce (Turcios-Casco and Medina-Fitoria 2019). Herein, we describe the importance of two caves in Ceguaca, Santa Bárbara in western Honduras based on the number of species recorded and the historical records of Santa Bárbara. Finally, we provide the first checklist of bat species of Santa Bárbara with a discussion regarding the importance of this Tropical Dry Forest that embrace two caves for bat conservation.

\section{Methods}

\section{Study area}

Three sites were studied in Ceguaca, Santa Bárbara in western Honduras (Figure 1). Site 1 in the locality of Quita Sueño $\left(1^{\circ} 46^{\prime} 32^{\prime \prime N}\right.$, 88 $8^{\circ} 12^{\prime} 00^{\prime \prime W} ; 299$ m), a crop of Zea mays (Poaceae) in the middle of a Tropical Dry Forest. One cave was studied in the

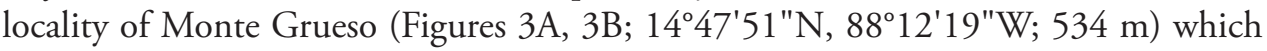




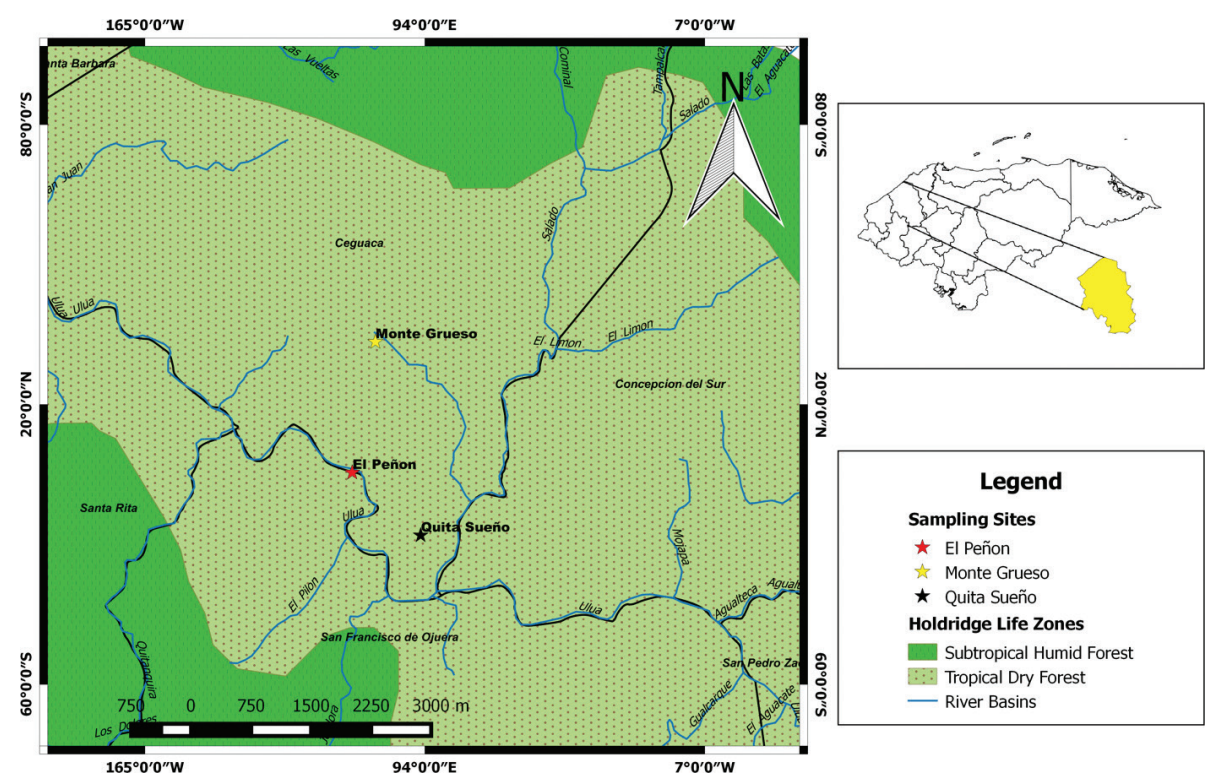

Figure I. Study sites at Ceguaca, Santa Bárbara in western Honduras. Note that near the Tropical Dry Forest of Ceguaca there are Humid Subtropical Forest. Also, the cave of El Peñon is located near Río Ulúa, one of the longest rivers in Honduras The life zones are based on Holdridge (1987). Map organized in QGIS software, version 2.18, Author: Diego Ordońez.

has an entrance of approximately $5 \mathrm{~m}$ beneath the ground and a width of $10 \mathrm{~m}$; the interior of the cave is divided into several branches, but the main branch is often used by bats for going in or out of the cave. The other cave was studied in the locality of

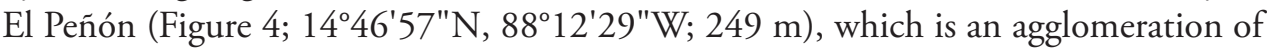
7 caves that are located riverside of the Río Ulúa; the entrance of the main cave has a height of approximately $3 \mathrm{~m}$, and five meters of width, while the others have a height between 1 to $2 \mathrm{~m}$, and a width of 2 to $3 \mathrm{~m}$.

In general, $54.65 \%$ of the vegetation coverage of Ceguaca are crops and grasslands, and the other percentage include vegetation of Tropical Dry Forest and Secondary Deciduous Vegetation (ICF 2015). Ceguaca have a mid-annual precipitation of $1,900 \mathrm{~mm}$, mid temperatures from $20-26^{\circ} \mathrm{C}$, and a mid-annual relative humidity from $78-79.4 \%$ (IHCIT 2012; Suazo Oliva 2014). Based on Holdridge (1987), the sites studied in Ceguaca are embraced on a Tropical Dry Forest. Plants species include: Aristolochia (Aristolochiaceae), Clusia (Clusiaceae), Crescentia (Bignoniaceae), Desmodium and Enterolobium, (Fabaceae), Ficus (Moraceae), Guazuma (Malvaceae) Ipomoea (Convolvulaceae), Mangifera (Anacardiaceae), Solanum (Solanaceae); as well as crops of $Z$. mays (Poaceae) and cattle.

\section{Sampling and bat identification}

From December 2015 to May 2016 we made seven surveys, using three mist-nets (9 $\times 2.5 \mathrm{~m}$ and $14 \times 2.5 \mathrm{~m}$; mesh of $35 \mathrm{~mm}$ ) that remained opened from 16:30 until 
4:30 $\mathrm{h}$ and were checked every 20 minutes. In some occasions they remain opened for monitoring birds until 9:00, but the sampling effort was not taken in account. The positions of the mist-nets were selected according to Kunz and Kurta (1988), based on the vegetation, topography, and bodies of water.

We determined the sex of the bats according to Kunz et al. (1996), and the biological age according to Brunet-Rossinni and Wilkinson (2009). We took measurements with a vernier with spire Mitutoyo (505-675) to the closest $0.01 \mathrm{~mm}$. Body mass was measured with a scale of 10 or $100 \mathrm{~g}$. We followed Timm et al. (1999), Medellín et al. (2008), and Aguirre et al. (2009) for the taxonomical identification of the bats. Finally, we followed the taxonomical proposals of Velazco and Patterson (2013), Simmons (2005), and Baker et al. (2016).

The following specimens were sacrificed according to the guidelines of the use of mammals in wildlife research (Rabinowitz et al. 2000; Kingston 2016; Sikes et al. 2016), and deposited in the Zoological Collection in the Escuela Agrícola Panamericana (EAP): Diphylla ecaudata (CZB-2019-1; CZB-2019-7), Glossophaga soricina (CZB-2019-2), Desmodus rotundus (CZB-2019-8), Sturnira parvidens (CZB-201913), Micronycteris schmidtorum (CZB-2019-14), Carollia subrufa (CZB-2019-15), and Dermanura phaeotis (CZB-2019-15).

\section{Species richness and sampling effort}

We estimated species richness based on our sampling effort and the abundance of each species using the software EstimateSMac 910 with 100 randomizations to eliminate the specific order of the data (Colwell and Coddington 1994; Colwell 2013). We made accumulation curves using Chao 1, Chao 2, and ICE as species richness estimators, and the sampling effort was calculated by the time each mist-net remained open during each survey (Moreno 2001; Rex et al. 2008).

\section{Results}

\section{Species richness and sampling effort}

We accumulated 74.27 mist-net/hours in seven journeys and captured 139 bats (1.87 individuals per mist-net/hour) belonging to 23 species ( 0.31 species per mist-net/hour) of four families ( 0.05 families per mist-net/hour). The sampling effort was distributed as the following: 39\% in the crops of Quita Sueño, 39\% in the cave of Monte Grueso, and 22\% in the cave of El Peñón. Based on Chao 1, Chao 2 and ICE (Table 2), we recorded between 41.71-64.95\% of the expected species in Ceguaca, Santa Bárbara (Figure 2), 10 species in the crops of Quita Sueño, 10 in the cave of El Peñón, and 12 in the cave of Monte Grueso. We captured 17\% of the individuals in the crop of Quita Sueño, 62\% in the cave of Monte Grueso, and 21\% in the cave of El Peñón. 


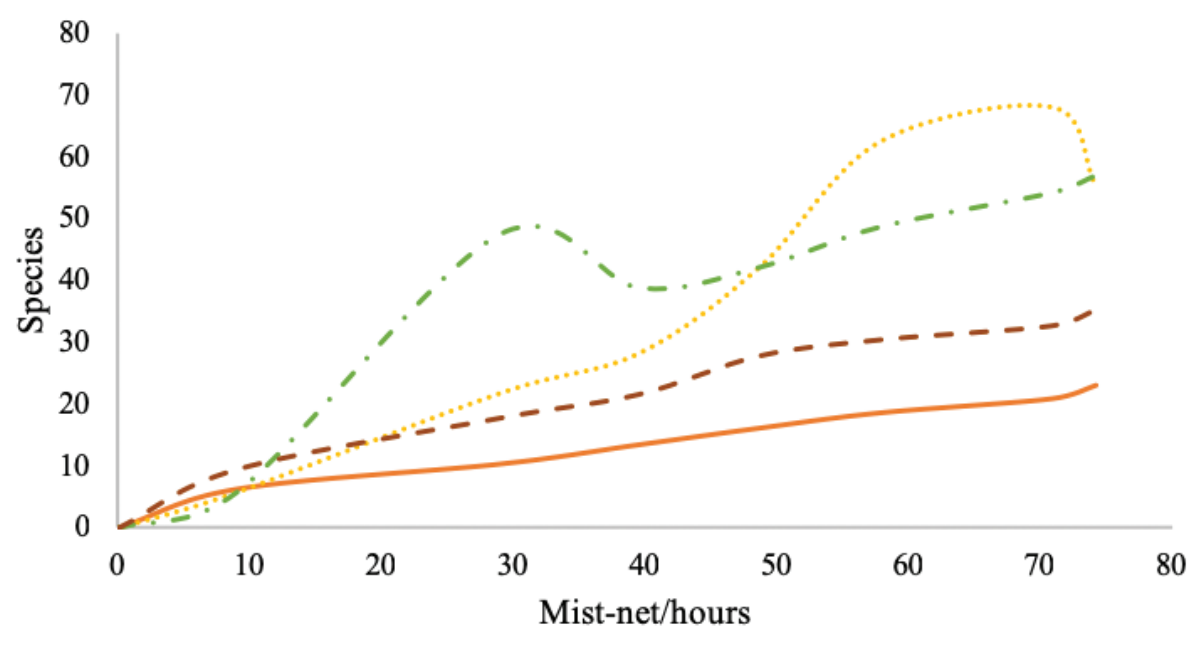

- Species recorded $\quad \cdots \cdot$.... Chao 2 - - ICE - - Chao 1

Figure 2. Species richness of bats in Ceguaca, Santa Bárbara based on the abundance of individuals captured during 2015 and 2016. Based on the estimator indexes, between 35.05 and 58.29\% of bat species are still unrecorded. None of these accumulation curves reached an asymptote, which reflects that more sampling effort is needed in the area.

In general, the most common family was Phyllostomidae with $83.5 \%$ of the captures, followed by Emballonuridae (13.7\%), Vespertilionidae (1.4\%), and Mormoopidae (1.4\%). The most common species was Glossophaga soricina with $28.8 \%$ of the captures, followed by Artibeus jamaicensis and D. rotundus with $27.3 \%$ of the captures and Peropteryx macrotis (12.2\% of the captures). The most uncommon species with one capture each were: Carollia subrufa, Chiroderma villosum, C. salvini, Dermanura phaeotis, D. tolteca, D. watsoni, Micronycteris microtis, M. schmidtorum, Myotis albescens, M. nigricans, and Sturnira parvidens (Table 1).

\section{Discussion}

\section{Caves in Honduras}

Hernández (2015) mentioned that only two caves have approval for tourism in Honduras: Taulabé, Comayagua (central Honduras) and Talgua, Olancho (eastern Honduras), but unfortunately are altered by footpaths and lightings. In Honduras, there is a cave declared as a SICOM (abbreviation in Spanish for Site with Importance for the Conservation of Bats) by the RELCOM (abbreviation in Spanish for Latin American Network for the Conservation of Bats), and PCMH (abbreviation in Spanish for Program for the Conservation of Bats in Honduras) known as Hato Viejo, a cave in which 

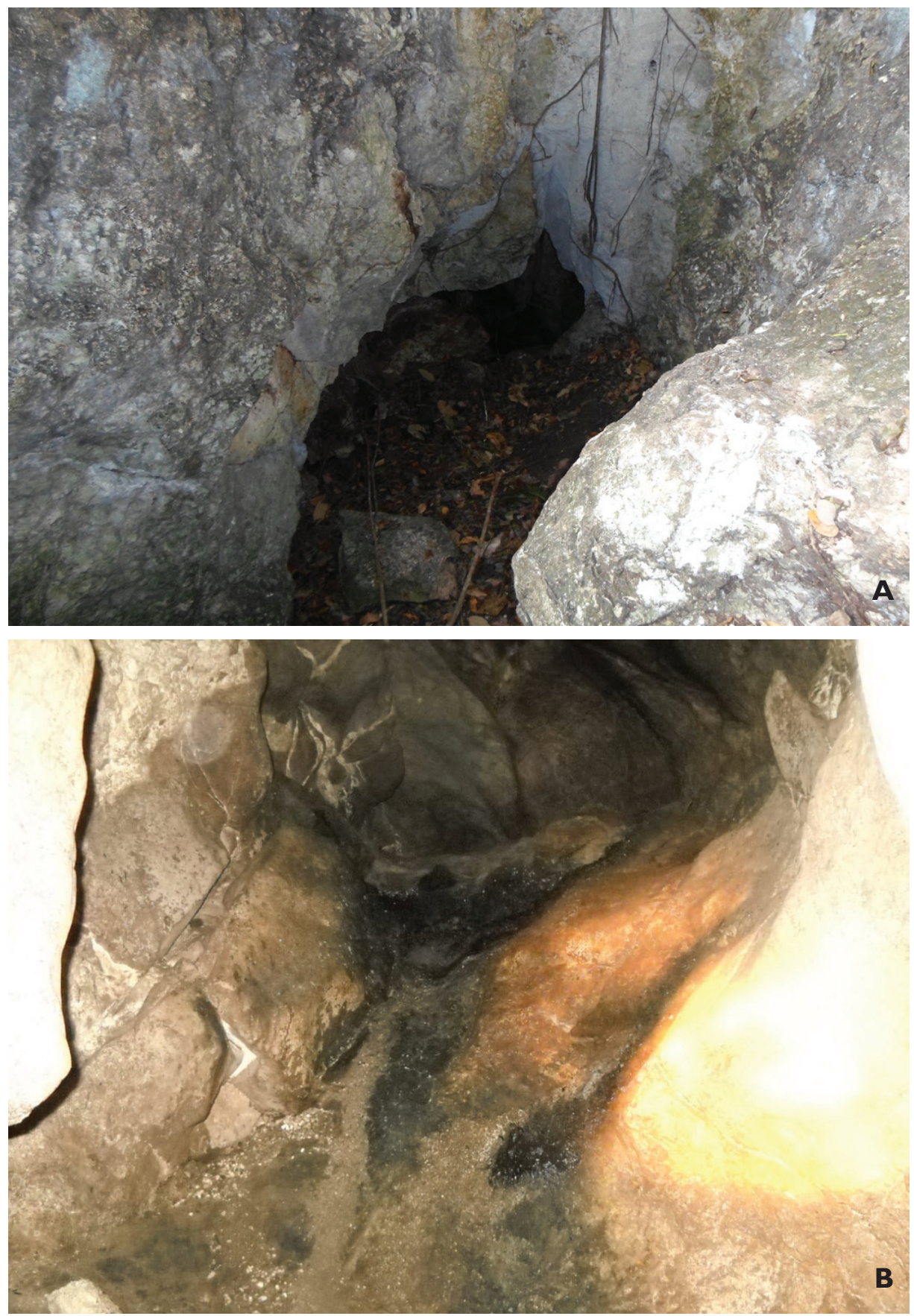

Figure 3. A the main entrance of the cave of Monte Grueso is a climb of approximately 5 meters drop. The inside of the cave is divided into tree branches. The photo was taken by Hefer Ávila B main branch of the cave, which is often used by the bats whenever they entered or exited the cave. Notice the guano in the floor of the cave of hematophagous bats (D. ecaudata and D. rotundus). The photo was taken by Manfredo Turcios Padgett. 

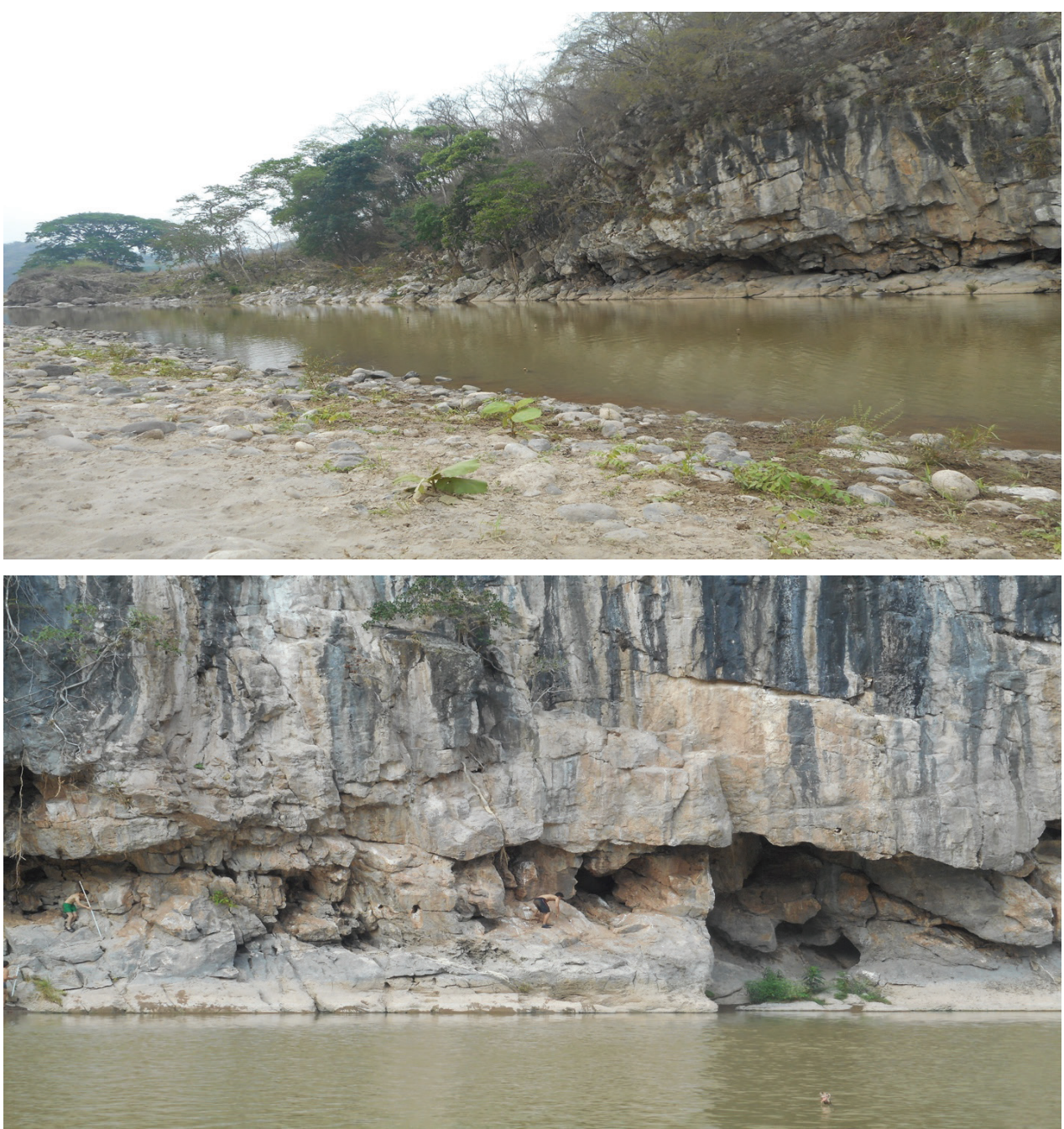

Figure 4. Caves of El Peñon are located riverside of Río Ulúa. This agglomeration of 7 caves is located riverside of the Río Ulúa. During the surveys we found an owl (Strigidae) coming out of the cave when the activity of the bats (18:00) started, and also, we found remains of the food belonging to a presumably Chironectes minimus (Didelphidae), that use rocks of these caves to eat fishes. The photos were taken by Hefer Ávila.

is estimated that 35,000 bats inhabit on it, and still is the biggest aggregation of bats in a natural refuge for Honduras.

\section{Conservation of bat caves}

Most of the species recorded on this study are typically recorded on intervened habitats, with the exception of species of Phyllostominae which are considered bioindicators of 
Table I. Checklist of bat species in Santa Bárbara including historical records. Abbreviations are defined as: 1 = Davis (1970); 2 = Dolan and Carter (1979); 3 = Davis (1984); 4 = McCarthy et al. (1993); 5 = Mora et al. (2018); EP = Cave of El Peñón; MG = Cave in Monte Grueso; QS = crops in Quita Sueño. The abundance presented on this table is based on the individuals captured during this study.

\begin{tabular}{|c|c|c|c|c|c|}
\hline No. & Family & Subfamily & Species, author and year & $\begin{array}{l}\text { Site in which was } \\
\text { captured and/or } \\
\text { historical records }\end{array}$ & Abundance \\
\hline 1 & Emballonuridae & & Balantiopteryx plicata Peters, 1867 & 4 & 0 \\
\hline 2 & & & Peropteryx macrotis (Wagner, 1843) & EP & 17 \\
\hline 3 & & & Rhynchonycteris naso (Wied-Neuwied, 1820) & $\begin{array}{l}\text { EP (captured in the } \\
\text { upstream of Río Ulúa) }\end{array}$ & 2 \\
\hline 4 & Mormoopidae & & Pteronotus personatus (Wagner, 1843) & EP & 2 \\
\hline 5 & Phyllostomidae & Micronycterinae & Micronycteris microtis Miller, 1898 & MG & 1 \\
\hline 6 & & & Micronycteris schmidtorum Sanborn, 1935 & QS, 4 & 1 \\
\hline 7 & & Lonchorhininae & Lonchorbina aurita Tomes, 1863 & 4,5 & 0 \\
\hline 8 & & Phyllostominae & Phyllostomus hastatus (Pallas, 1767) & 4 & 0 \\
\hline 9 & & Desmodontinae & Desmodus rotundus (É. Geoffroy, 1810) & EP, MG, QS & 19 \\
\hline 10 & & & Diphylla ecaudata Spix, 1823 & MG & 5 \\
\hline 11 & & Glossophaginae & Glossophaga leachii Gray, 1844 & MG & 2 \\
\hline 12 & & & Glossophaga soricina (Pallas, 1766) & MG, QS & 40 \\
\hline 13 & & Carollinae & Carollia castanea H. Allen, 1890) & MG & 3 \\
\hline 14 & & & Carollia perspicillata (Linnaeus, 1758) & MG & 4 \\
\hline 15 & & & Carollia sowelli Baker, Solari \& Hoffmann, 2002 & EP, MG, QS & 6 \\
\hline 16 & & & Carollia subrufa (Hahn, 1905) & EP & 1 \\
\hline 17 & & Stenodermatinae & Artibeus jamaicensis Leach, 1821 & MG, QS, 1 & 19 \\
\hline 18 & & & Artibeus lituratus (Olfers, 1818) & MG, QS, 3 & 8 \\
\hline 19 & & & Chiroderma salvini Dobson, 1878 & MG & 1 \\
\hline 20 & & & Chiroderma villosum Peters, 1860 & QS & 1 \\
\hline 21 & & & Dermanura phaeotis (Miller, 1902) & QS & 1 \\
\hline 22 & & & Dermanura tolteca Saussure, 1860 & QS & 1 \\
\hline 23 & & & Dermanura watsoni (Thomas, 1901) & MG & 2 \\
\hline 24 & & & Sturnira parvidens (Goldman 1917) & QS & 1 \\
\hline 25 & Natalidae & & Natalus stramineus Gray, 1838 & 4 & 0 \\
\hline 26 & Vespertilionidae & Myotinae & Myotis albescens (É. Geoffroy, 1806) & EP & 1 \\
\hline 27 & & & Myotis nigricans (Schinz, 1821) & EP & 1 \\
\hline \multirow[t]{2}{*}{28} & Molossidae & & Molossus sinaloae J.A. Allen, 1906 & 2 & 0 \\
\hline & Total & & & & 139 \\
\hline
\end{tabular}

well-conserved areas in the sites in which they forage and live, maintaining themselves fragile to the changes of their habitats (Emmons and Feer 1997). In accordance with Vela-Vargas and Pérez-Torres (2012), we identified that the Tropical Dry Forest in Ceguaca is undergoing deforestation, as well as in Dry Forests of Colombia, due to two main reasons: (1) fragmentation of the forest for crops of Zea mays, and (2) extensive livestock around remnants of Tropical Dry Forests.

If we considered the number of species reported by Mora et al. (2018), 9\% of bat species of the total account for Honduras could be found in the cave of El Peñon, and $11 \%$ in the cave of Monte Grueso. We must consider that some of the species re- 
Table 2. Accumulation of individuals, mist-net hours, species recorded and expected based on statistical estimators (Chao 2, ICE and Chao 1). Sample sites 1, 2 and 5 were in Quita Sueño; 3 and 4 were in Monte Grueso; 6 and 7 were in El Peñón.

\begin{tabular}{lcccccc}
\hline Samples sites & Individuals & Mist-net/hours & Species recorded & Chao 2 & ICE & Chao 1 \\
\hline 1 & 19.86 & 9.03 & 6.29 & 5.81 & 5.81 & 9.52 \\
2 & 39.71 & 29.03 & 10.33 & 21.82 & 47.62 & 17.85 \\
3 & 59.57 & 39.54 & 13.43 & 28.22 & 38.89 & 21.67 \\
4 & 79.43 & 48.715 & 16.11 & 42.16 & 42.22 & 27.92 \\
5 & 99.29 & 57.89 & 18.57 & 62.48 & 48.77 & 30.53 \\
6 & 119.14 & 70.97 & 20.86 & 68.02 & 54.33 & 32.81 \\
7 & 139 & 74.27 & 23 & 55.14 & 57.13 & 35.41 \\
\hline
\end{tabular}

corded only in the crops of Quita Sueño, could be also living in the caves of El Peñón and Monte Grueso (e.g. Micronycteris schmidtorum). Interestingly, if we considered the number of the species that have been recorded since 1979, between the 20.9 and $49.2 \%$ of the species expected are still unrecorded. Besides the diversity of bats that can be encountered in those caves and based on the comments of people of the community in Ceguaca, another importance of the cave of Monte Grueso is its use by pregnant females of White-tailed deer (Odocoileus virginianus, national mammal of Honduras) as a refuge. Remarkably, we recorded individuals of $C$. perspicillata and G. soricina returning at 4:00 $\mathrm{h}$ to the caves of Monte Grueso, as well as a record of $C$. perspicillata captured at 9:00 h returning from the crops of $Z$. mays to the Tropical Dry Forests in Quita Sueño (these records could reveal different activity patterns from the usual). Also, people from the community have encountered crystalized teeth of mammals, fragments of bones, obsidian, and artifacts such as vessels of clay with printings on them. These caves could not only represent an importance for the conservation of bats but also for knowing more about an unstudied culture of the area.

Based on Mora et al. (2018), D. ecaudata (Figure 7) is a species that is considered threatened in Honduras, specifically due to the human-vampire conflicts, and these caves could represent one of their principal refuges for conservation. Moreover, after the additional records of $M$. schmidtorum by McCarthy et al. (1993), there is one more record of this species in northwestern Honduras, in Cusuco National Park in Cortés by EstradaVillegas et al. (2007). The record of this species might represent the first one after eight years. Additionally, we encountered pregnant females of Pteronotus personatus (May; Figure 5), Peropteryx macrotis (May), Artibeus jamaicensis (December), Desmodus rotundus (December), Carollia subrufa (May), and females in lactation period of Myotis albescens (May) and Sturnira parvidens (December). Reproductive males of Artibeus lituratus (December), Desmodus rotundus (January), Glossophaga leachii (January), and G. soricina (January), were also recorded. Importantly, these caves could represent their primary roosting site and nursery when they have newborns. Destroying and not protecting those caves could determine the decrease of the populations of bats specialized in seed dispersal, pollination (Figure 6) as well as controlling pest species (e.g. insects of crops) in Ceguaca. 


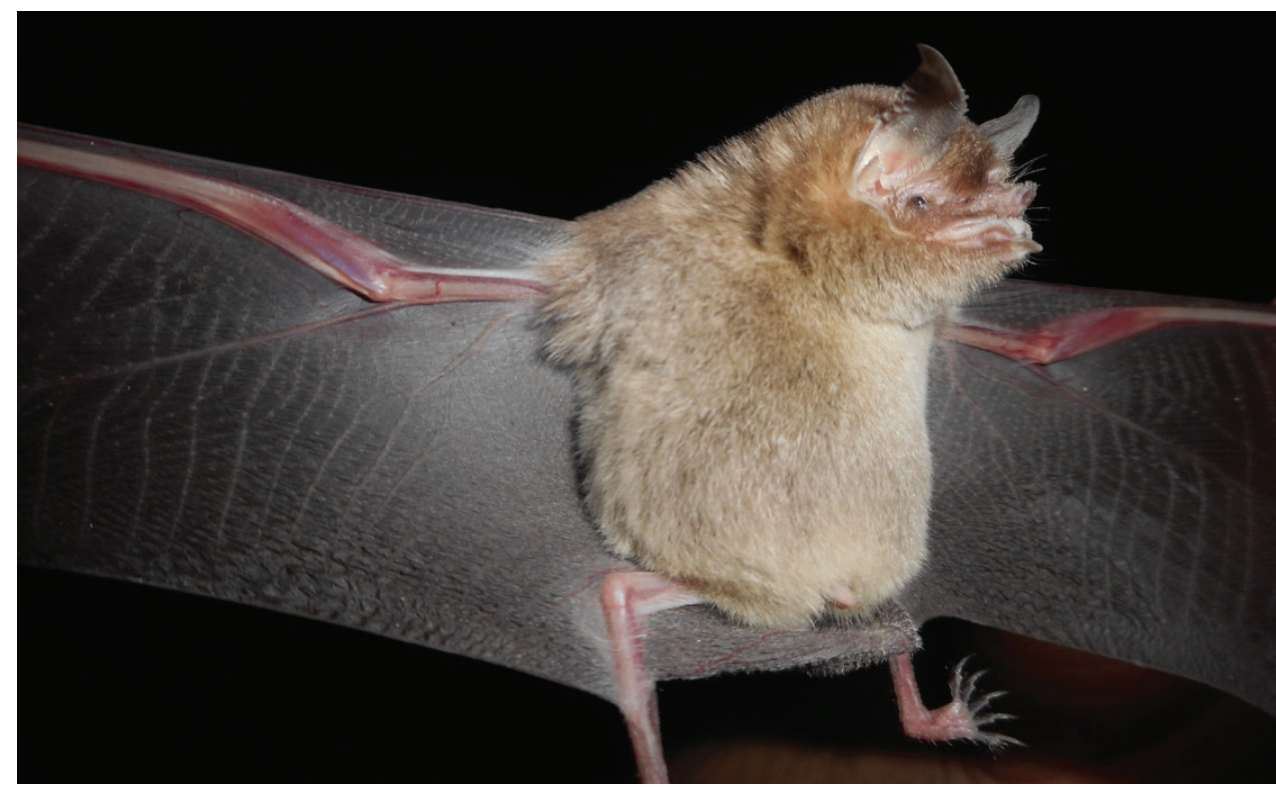

Figure 5. Pregnant female of Pteronotus personatus in the Cave of El Peñón during the survey of May 8 , 2016. The photo was taken by Hefer Ávila.

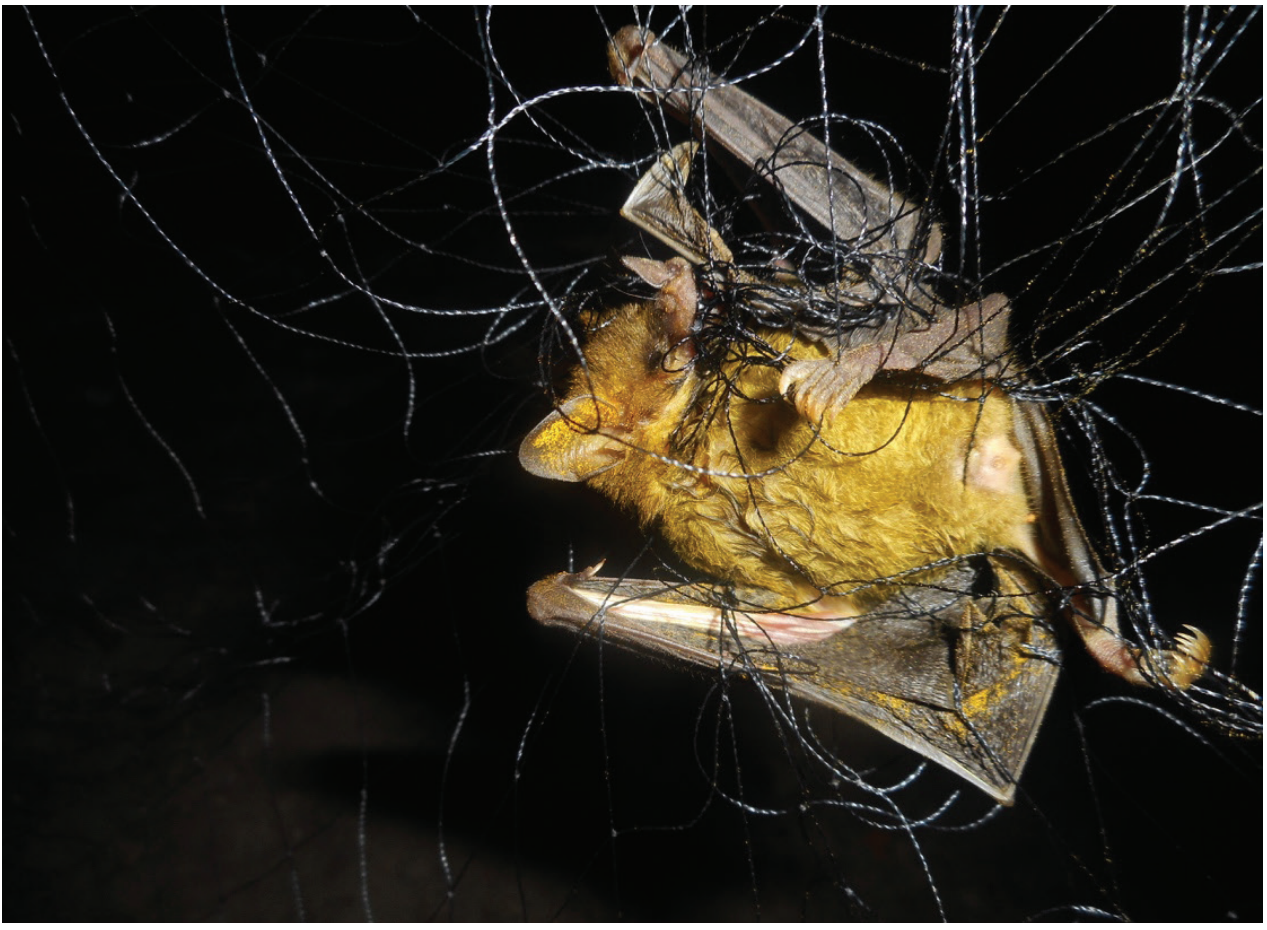

Figure 6. An adult female of Glossophaga soricina returning to the cave of Monte Grueso after the pollination of certain species of plants. During these surveys, we found trees with opened flowers of Crescentia alata (Bignoniaceae). The photo was taken by Hefer Ávila. 


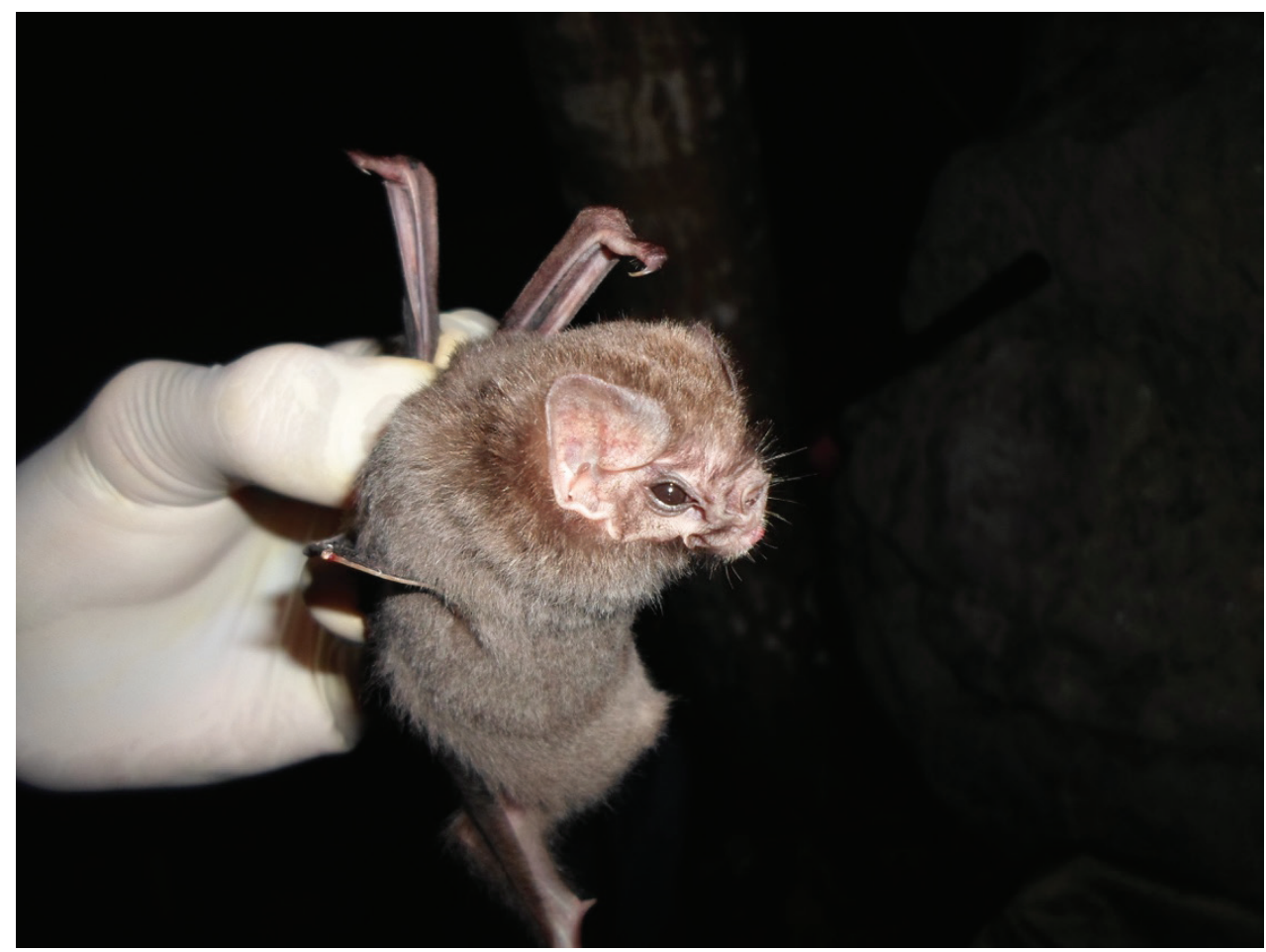

Figure 7. Adult female of Diphylla ecaudata captured in the cave of Monte Grueso when leaving the cave for searching food. The shelters of this unstudied species in Honduras in Monte Grueso could represent an important site for their conservation. The photo was taken by Hefer Ávila.

\section{Importance of bat caves in Ceguaca}

We encountered 0.30 species per mist-nets/hours on those located in the Tropical Dry Forest in Ceguaca. This result is comparably higher to other studies in different Dry Forests of America, for example: Chávez and Ceballos (2001) reported 15 species in a Dry Forest in Jalisco, México with a sampling effort of $410 \mathrm{mist}$-net/hours (0.04 species per mist-net/hours); Medina et al. (2004) reported 24 species in a Dry Forest in Rivas, Nicaragua, with a sampling effort of 5376 mist-net/hours $(0.005$ species per mist-net/hours); Vela-Vargas and Pérez-Torres (2012) reported 20 species in a Tropical Dry Forest in El Refugio, Colombia, with a sampling effort of 4673 mist-net/hours (0.004 species per mist-net/hours); and Ramírez Fráncel et al. (2015) recorded 10 species with a sampling effort of 7776 mist-net/hours (0.001 species per mist-net/hours) in Tolima, Colombia. Although, there is a low sampling effort in our study, the richness represented is higher in comparison to other studies with a higher sampling effort. However, the asymptote of the accumulation curves was not reached, and more effort is needed to support the high diversity estimated.

The Dry Forests of Honduras are one of the most threatened ecosystems due to the continuous fragmentation processes of habitats that are related to the use of soil in crops, cattle, and other agricultural systems. We conclude that the fragmentation of ecosystems 
in Ceguaca, is due to the following reasons: extensive cattle raising, replacement of native plants with extensions of grasslands for crops, and human-vampire conflicts $(D$. rotundus) which lead to intentional fires in the caves caused by the demonized concept of bats in the area, for example, the caves of El Peñón have been set on fire at least three times in the last five years. This study represents the first preliminary inventory of those caves on that Tropical Dry Forest. Thus, we strongly recommend the continuity of this study for a longer period of time, including wet and dry seasons, with a greater sampling effort. Furthermore, other methodologies to study bats must be included: harp nets, pulley nets, and vocalization recording. Finally, with this baseline, we hope to encourage the PCMH to declare these diverse caves as AICOMS (abbreviation in Spanish for Areas with Importance for the Conservation of Bats) for their conservation.

\section{Acknowledgments}

We dedicate this work to "Don Beto" (Gilberto Castellano Castellano) who now rests in peace and without his dedication and love to the conservation of the Biodiversity in Ceguaca this work could never be done; to Virginia Trochez, Rene Castellano Troches, Luis Pineda, Erick Amaya, Armando Arriaga and Alex Rodriguez who are the new caretakers of the Biodiversity of Ceguaca; to Marcio Alvarado, Ivonne Padgett, Jeffrey Padgett and Luis Padgett for their kindness in letting use their lands; to Manfredo Turcios Padgett, Javier Zúniga, Leonardo Nuñez and Danny Ordoñez for their field assistance and permission to use their photos of the surveys; and to ICF for the research and collection permit: Resolución-DE-MP-07-2017.

\section{References}

Aguirre L, Vargas A, Solari S (2009) Clave de campo para la identificación de los murciélagos de Bolivia. Centro de Estudios en Biología Teórica y Aplicada (BIOTA), Cochabamba, 38 pp.

Baker RJ, Solari S, Cirranello A, Simmons NB (2016) Higher level classification of phyllostomid bats with a summary of DNA synapomorphies. Acta Chiropterologica 18: 1-18. https://doi.org/10.3161/15081109ACC2016.18.1.001

Bichuette ME, do Amaral Gimenez E, Arnone IS, Trajano E (2018) An important site for conservation of bats in Brazil: Passa Três cave, Sao Domingos karst area, with an updated checklist for Distrito Federal (DF) and Goiás state. Subterranean Biology 28: 39-51. https://doi.org/10.3897/subtbiol.28.31801

Brunet-Rossinni A, Wilkinson G (2009) Methods for age estimation and the study of senescence in bats. In: Kunz TH, Parsons S (Eds) Ecological and behavioral methods for the study of bats. The John Hopkins University Press, Baltimore: 315-325.

Chávez C, Ceballos G (2001) Diversidad y abundancia de murciélagos en selvas secas de estacionalidad contrastante en el oeste de México. Revista Mexicana de Mastozoología 5: 27-44. 
Colwell RK (2013) EstimatesS (version 9): statistical estimation of species richness and shared species from sample. http://www.purl.oclc.org/estimates [Accessed at January 2018]

Colwell RK, Coddington JA (1994) Estimating terrestrial biodiversity through extrapolation. Philosophical Transactions: Biological Sciences 345(1311): 101-118. https://doi. org/10.1098/rstb.1994.0091

Davis WB (1970) The large fruit bats (genus Artibeus) of Middle America, with a review of the Artibeus jamaicensis complex. Journal of Mammalogy 51(1): 105-122. https://doi. org/10.2307/1378537

Davis WB (1984) Review of the large fruit-eating bats of the Artibeus "lituratus" complex (Chiroptera: Phyllostomidae) in Middle America. Occasional Papers The Museum Texas Tech University 93: 1-16. https://doi.org/10.5962/bhl.title.156552

Deleva S, Chaverri G (2018) Diversity and conservation of cave-dwelling bats in the Brunca Region of Costa Rica. Diversity 10(2): 1-15. https://doi.org/10.3390/d10020043

Dolan PG, Carter DC (1979) Distributional notes and records for Middle American Chiroptera. Journal Mammalogy 60(3): 644-649. https://doi.org/10.2307/1380115

Divoll TJ, Buck DG (2013) Noteworthy field observations of cave roosting bats in Honduras. Mastozoología neotropical 20(1): 149-151.

Emmons L, Feer F (1997) Neotropical rainforest mammals, a field guide. The University of Chicago Press, Chicago, 368 pp.

Estrada-Villegas SL, Allen M, García M, Hoffman M, Munroe ML (2007) Bat assemblage composition and diversity of the Cusuco National Park, Honduras. Operation Wallacea, San Pedro Sula, 6 pp.

Furey NM, Racey PA (2016) Conservation ecology of cave bats. In: Voigt C, Kingston T (Eds) Bats in the anthropocene: conservation of bats in a changing world. Springer, Cham: 463500. https://doi.org/10.1007/978-3-319-25220-9_15

Hernández DJ (2015) Programa para la conservación de los murciélagos de Honduras (PCMH). In: Rodríguez Herrera B, Sánchez R (Eds) Estrategia centroamericana para la conservación de los murciélagos. Sistema Editorial y de Difusión de la Investigación, San José, 41-55.

Holdridge L (1987) Ecología basada en zonas de vida (Trad. H. Jiménez Saa). Instituto Interamericano de Cooperación para la Agricultura (IICA), San José, 216 pp.

ICF (2015) Atlas municipal forestal y cobertura de la tierra. Municipio de Ceguaca, Santa Bárbara. Comayagüela, MDC, 43 pp.

IHCIT (2012) Atlas climático y de gestión de riesgo de Honduras. Cooperación Suiza en América Central, Tegucigalpa. MDC, 148 pp.

Kingston T (2016) Bats. In: Larsen L (Ed.) Core standardized methods for rapid biological field assessment. Conservation International, Virginia, 59-82.

Kunz TH, Kurta A (1988) Capture methods and holding devices. In: Kunz TH (Ed.) Ecologi$\mathrm{cal}$ and behavioral methods for the study of bats. Smithsonian Institution Press, Washington DC, 1-28.

Kunz T, Wemmer C, Hayssen V (1996) Sex, age, and reproductive condition of mammals. In: Wilson DE, Nichols J, Rudrin R, Cole R, Foster M (Eds) Measuring and monitoring biological diversity. Smithsonian Institution Press, Washington DC, 279-290. 
McCarthy TJ, Davis WB, Hill JE, Jones Jr. JK, Cruz GA (1993) Bat (Mammalia: Chiroptera) records, early collectors, and faunal lists for northern Central America. Annals Carnegie Museum 62: 191-228.

Medellín R, Arita H, Sánchez O (2008) Identificación de los murciélagos de México, clave de campo. Ed. 2. Universidad Nacional Autónoma de México (UNAM), Distrito Federal, 83 pp.

Medellín RA, Wiederholt R, Lopez-Hoffman L (2017) Conservation relevance of bat caves for biodiversity and ecosystem services. Biological Conservation 211: 45-50. https://doi. org/10.1016/j.biocon.2017.01.012

Medina A, Harvey C, Sánchez D, Vilchez S, Hernández B (2004) Diversidad y composición de Chiropteros en un paisaje fragmentado de bosque seco en Rivas, Nicaragua. Revista Encuentro 68: 24-43. https://doi.org/10.5377/encuentro.v0i68.4255

Mora JM, López LI, Espinal M, Marineros L, Ruedas L (2018) Diversidad y Conservación de los murciélagos de Honduras. Master Print S. de R.L., Tegucigalpa, 300 pp.

Moreno CE (2001) Métodos para medir biodiversidad. M\&T-Manuales y Tesis SEA, Zaragoza, $84 \mathrm{pp}$.

Rabinowitz A, Hart J, White L (2000) Information from dead animals and their curation. In: White LJ, Edwards A (Eds) Conservation research in the African rain forests: a technical handbook. Wildlife Conservation Society, New York, 185-195.

Ramírez Fráncel LA, Rivas Pava M del P, Reinos Flórez G (2015) Murciélagos insectívoros de dos fragmentos de bosque seco tropical, Tolima-Colombia. Revista de la Asociación Colombiana de Ciencias Biológicas 27: 32-41.

Rex K, Kelm DH, Wiesner K, Kunz TH, Voigt CC (2008) Species richness and structure of three Neotropical bat assemblages. Biological Journal of the Linnean Society 94(3): 617-629. https://doi.org/10.1111/j.1095-8312.2008.01014.x

Rodríguez-Durán A (1998) Nonrandom aggregations and distribution of cave-dwelling bats in Puerto Rico. Journal of Mammalogy 79: 141-146. https://doi.org/10.2307/1382848

Rodríguez-Durán A (2009) Bat assemblages in the West Indies: the role of caves. In: Fleming TH, Racey PA (Eds) Island bats: evolution, ecology and conservation. University of Chicago Press, Chicago, 279-290.

Sikes RS, Animal Care and Use Committee of the American Society of Mammalogists (2016) Guidelines of the American Society of Mammalogists for the use of wild mammals in research and education. Journal of Mammalogy. 97: 663-688. https://doi.org/10.1093/ jmammal/gyw078

Simmons N (2005) Order Chiroptera. In: Wilson DE, Reeder DM (Eds) Mammal species of the world: a taxonomic and geographic reference $\left(3^{\text {rd }}\right.$ edn). The Johns Hopkins University Press, Baltimore, 312-529.

Suazo Oliva EA (2014) Propuesta para la implementación de un manual de procedimientos administrativos de la municipalidad de Ceguaca, departamento de Santa Bárbara. Tesis MSc, Universidad Nacional Autónoma de Honduras, Tegucigalpa, M.D.C., 113 pp.

Timm RM, LaVal RK, Rodríguez-H B (1999) Clave de campo para los murciélagos de Costa Rica. Brenesia 52: 1-32. 
Turcios-Casco MA, Medina-Fitoria A (2019) Occurrence of Hylonycteris underwoodi (Chiroptera, Phyllostomidae) and Thyroptera tricolor (Chiroptera, Thyropteridae) in Honduras. Studies on Neotropical Fauna and Environment 54(1): 69-72. https://doi.org/10.1080/0 1650521.2018 .1544205

Vela-Vargas M, Pérez-Torres J (2012) Murciélagos asociados a remanentes de bosque seco tropical en un sistema de ganadería extensiva (Colombia). Chiroptera Neotropical 18(1): 1089-1100.

Velazco PM, Patterson BD (2013) Diversification of the yellow-shouldered bats, genus Sturnira (Chiroptera, Phyllostomidae), in the new world tropics. Molecular Phylogenetics and Evolution 68(3): 683-698. https://doi.org/10.1016/j.ympev.2013.04.016 